\title{
Ten year incidence of HCV infection in northern Italy and frequency of spontaneous viral clearance
}

\author{
C Mazzeo, F Azzaroli, S Giovanelli, A Dormi, D Festi, A Colecchia, A Miracolo, \\ P Natale, G Nigro, A Alberti, E Roda, G Mazzella
}

\begin{abstract}
Background: Little is known of the incidence of hepatitis $\mathrm{C}$ virus (HCV) infection, and the frequency of spontaneous viral clearance in the general population is unknown. We conducted an epidemiological study in two Apennine towns in northern Italy.

Methods: Anti-HCV (ELISA and RIBA third generation) and HCV-RNA by polymerase chain reaction were tested in thawed sera from an adult general population of Loiano-Monghidoro in 1986 and 1996, obtained in the context of the MICOL (Multicenter Italian Study on Cholelithiasis). In 1999, anti$\mathrm{HCV}$ positive subjects and sex and age matched controls were recalled in order to identify risk factors for acquiring $\mathrm{HCV}$ infection and to assess the family composition of anti- $\mathrm{HCV}^{+}$subjects. Results: For 1646 subjects, sera were available from both 1986 and 1996 (mean age in 198643 (0.39) years). In 1986, 57 (3.46\%) subjects were HCV antibody positive (HCV-Ab+). Eight new cases were recorded in 1996: adult incidence was 50.3 cases/100 000 inhabitants/year. Fifty three of 63 $(84.1 \%) \mathrm{HCV}-\mathrm{Ab}^{+}$sera were also HCV-RNA+. Genotype $2 \mathrm{a} / 2 \mathrm{c}$ accounted for $44 \%$ and $1 \mathrm{~b}$ for $47.0 \%$ of cases. $\mathrm{HCV}-\mathrm{Ab}^{+}$subjects had higher serum levels of alanine aminotransferase with respect to controls $(p<0.005)$, as did subjects infected with genotype 1 with respect to those with genotype 2 $(\mathrm{p}<0.05)$. Eleven of 65 (16.9\%) HCV-Ab+ subjects spontaneously cleared HCV-Ab; 7/11 also lost HCV-RNA ${ }^{-}$in both serum and leucocytes. Sixteen anti-HCV+ subjects belonged to families containing more than one infected member. Married couples accounted for 10 of these 16 subjects. In four of these five married couples, HCV genotype was identical in the two spouses.

Conclusions: In rural northern Italy, the adult incidence of HCV is approximately 50 cases/100 000 inhabitants/year. Our findings suggest that as many as $17 \%$ of infected subjects may spontaneously clear HCV-Ab. Interfamilial transmission seems to have a role in the spread of infection.
\end{abstract}

See end of article for authors' affiliations

Correspondence to: Dr G Mazzella

Dipartimento di Medicina Interna e Università di Bolog, Policlinico S

Orsola-Malpighi, Via Massarenti 9, 40138 Bologna, Italy;

mazzella@med.unibo.it

Accepted for publication

21 February 2003

$\mathrm{H}$ epatitis $\mathrm{C}$ virus (HCV) infection is recognised as a major cause of chronic liver disease. Worldwide, the overall prevalence of HCV infection is thought to average approximately $3 \%$, accounting for $\sim 150-200$ million carriers, even though large differences exist among different geographic regions and age groups. ${ }^{1} \mathrm{HCV}$ prevalence is highly variable worldwide, ranging from $0.01 \%$ in the UK and Scandinavia to $26 \%$ in Egypt and certain areas of southern Italy. There are thought to be approximately four million infected subjects in the USA ${ }^{2}$ and five million in Western Europe, ${ }^{3}$ more than one million of whom are found in Italy. ${ }^{4}$ The few studies on the prevalence of HCV infection among the general population in Italy suggest an average value of approximately $7-8 \%$, increasing with age and from northern to southern regions. ${ }^{5-7}$ One previous study on the incidence of HCV infection in Italy reported 34.2 new cases/100 000 inhabitants/ year. ${ }^{8}$ However, this study investigated a cohort of individuals from southern Italy with a very high prevalence of infection $(26 \%)$ and may not have been representative of the Italian general population.

Major gaps exist in our knowledge of HCV infection among the general population. While many epidemiological studies have been published on high risk or other selected subgroups, much less information exists about prevalence and, especially, incidence of HCV infection in the general population at large. Furthermore, most assessments of genotype distribution have been conducted in groups of patients under medical surveillance rather than the general population. ${ }^{4}$ Another important gap in our knowledge regards spontaneous clearance of the virus. Although it is known that HCV infection can sometimes be cleared spontaneously without the need for treatment, it is not known in what percentage of cases this occurs. From a health planning perspective, a better understanding of the burden and natural history of HCV infection in the general population is therefore a priority.

We investigated these issues in the general population in northern Italy. Based on the MICOL (Multicenter Italian Study on Cholelithiasis) national epidemiological study on the prevalence of (gall bladder) cholelithiasis," we analysed the incidence of HCV infection and genotype distribution in a representative cohort of adult subjects from the general population of two Apennine hill towns in northern Italy. A total of 1646 adults were tested for HCV in 1986 and again in 1996. Subjects who were found to be positive for the HCV antibody $\left(\mathrm{HCV}-\mathrm{Ab}^{+}\right)$in 1996 were re-evaluated in 1999 in comparison with controls matched for sex and age. The frequency of spontaneous viral clearance without treatment was analysed, as was interfamilial spreading.

\section{MATERIALS AND METHODS}

Demography and study design (fig 1)

The study involved the general population of Loiano and Monghidoro (Bologna), two small Apennine hill towns in the Emilia-Romagna region of northern Italy. The adult population of these two towns is fairly stable (totalling 3572). All subjects aged 18-69 years who were resident in Loiano and Monghidoro were called. Out of a total of 3572 citizens, 1847

Abbreviations: $\mathrm{HCV}$, hepatitis $\mathrm{C}$ virus; $\mathrm{HCV}-\mathrm{Ab}, \mathrm{HCV}$ antibody; RT-PCR, reverse transcriptase-polymerase chain reaction; ALT, alanine aminotransferase; OD, optical density; IFN, interferon $\alpha$. 


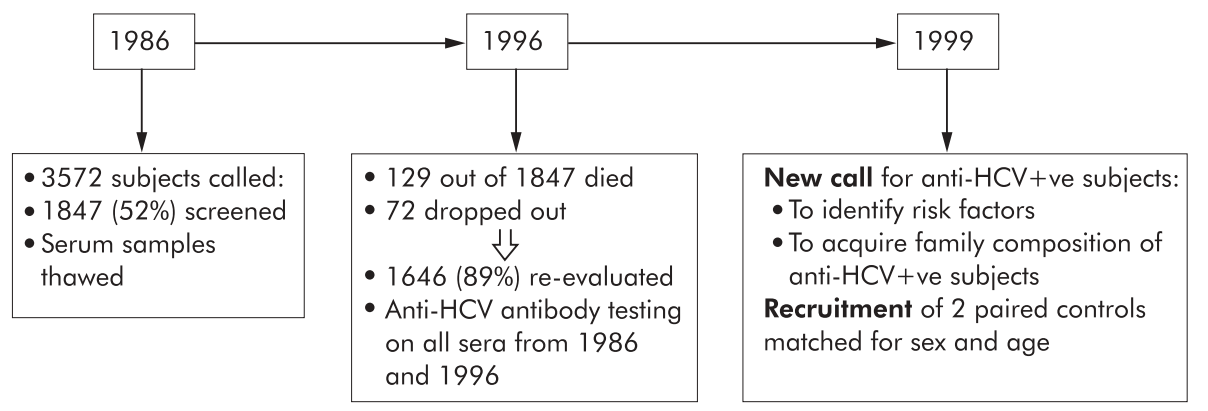

Figure 1 Study design. HCV, hepatitis $C$ virus.

$\begin{aligned} & \text { Table } 1 \text { Demographics of the study } \\ & \text { population }\end{aligned}$
$\begin{array}{ll}\mathrm{n} & 1646 \\ \text { Mean (SD) age }(y) & 43.79(15.95) \\ \text { Sex (M:F) } & 852: 794=1.07: 1\end{array}$

Table 2 Demographics of the study population in 1996 in relation to hepatitis $C$ virus positivity

\begin{tabular}{lll}
\hline & Anti-HCV (1996) & Controls (1996) \\
\hline $\mathrm{n}$ & 63 & 126 \\
Mean (SD) age (y) & $60.68(10.64)$ & $60.26(11.01)$ \\
Sex (M:F) & $31: 32=1: 1.03$ & $62: 64=1: 1.03$ \\
\hline & & \\
\hline
\end{tabular}

adult subjects (52\%) voluntarily enrolled for screening of cholelithiasis in 1986 in cooperation with their family doctors. All of these subjects were invited to return for a further screening in 1996 in the context of the MICOL, for evaluating the incidence and risk factors of cholesterol gall stone disease. During the second population screening, all subjects gave informed consent that their serum samples (obtained both in 1986 and 1996) would be tested for anti-HCV and hence retrospective analyses of anti-HCV antibodies were made on all sera obtained in 1986. A total of 1646 subjects of 1847 studied in 1986 ( 129 subjects had died and 72 had dropped out) were effectively re-evaluated in 1996; population demographics are reported in tables 1 and 2. Sera collections were obtained over a period of three months in both 1986 and 1996

All sera were screened for HCV-Ab; for those found to be positive, HCV-RNA by polymerase chain reaction (PCR) and genotype were determined when appropriate. All subjects $\mathrm{HCV}-\mathrm{Ab}^{+}$in 1996 were recalled in 1999 for the purposes of: identifying risk factors for $\mathrm{HCV}$ infection through accurate anamnesis performed by medical doctors; acquiring the family composition of anti- $\mathrm{HCV}^{+}$subjects (interviews were performed by SG, AM, and PN); obtaining informed consent for publication of the results; recruiting two randomly selected paired controls matched for sex and age; and informing patients of their anti-HCV status. On this occasion, a new blood sample collection was obtained to evaluate HCV-RNA in both serum and leucocytes in those subjects who had become negative for HCV-RNA in serum. All controls were still anti-HCV-Ab negative in 1999.

In line with Italian legislation, the Local Health Authority (ASL) approved the study, and subjects provided written authorisation for publication of the data.

\section{Laboratory tests}

Anti-HCV-Ab

Anti-HCV-Ab was tested in all serum samples using a third generation enzyme linked immunosorbent assay (ELISA III;
Ortho Diagnostic Systems, Raritan, New Jersey, USA). All anti-HCV-Ab ${ }^{+}$samples were confirmed by third generation recombinant immunoblot assay (RIBA III; Ortho Diagnostic Systems/Chiron).

\section{HCV-RNA and genotypes}

When a serum sample was anti-HCV (even only once), all samples of that patient were tested for HCV-RNA by nested reverse transcriptase-PCR (RT-PCR, sensitivity < 100 copies/ $\mathrm{ml}$ ). HCV RNA was tested on total RNA extracted from serum using the Estrazol kit (Bioline Diagnostici, Turin, Italy) or in leucocytes immediately isolated from blood according to standard dextran based methods in an RNAse free environment. ${ }^{10}{ }^{11}$ HCV-RNA positivity was evaluated by RTPCR with primers based on the $5^{\prime}$ untranslated region of the genome (RT kit; Bioline Diagnostici). ${ }^{.213}$

HCV genotype was evaluated in all sera from subjects testing positive for HCV-RNA and, whenever necessary, on RNA extracted from leucocytes. Genotype was determined by nested RT-PCR using type specific primers (INNO-LiPA HCV II; Innogenetics NV, Ghent, Belgium) ${ }^{14}$ and classified according to the criteria of Simmond and colleagues. ${ }^{15}$

\section{Statistical analysis}

Descriptive statistical analysis was performed for all parametric variables (HCV-Ab and/or HCV-RNA positivity/negativity, alanine aminotransferase (ALT) levels) using the Student's $t$ test to assess significance. For subgroup analysis, univariate variance analysis was performed using the Tukey and Bonferroni restriction tests. Non-parametric variables were analysed using Pearson, Fisher, Mann-Whitney, and Kruskal-Wallis tests. SPSS version 9 for Windows was used.

\section{RESULTS}

\section{Prevalence and incidence of HCV infection and} spontaneous viral clearance (fig 2)

In 1986, the overall adult prevalence of HCV-Ab positivity was $3.46 \%(57 / 1646$ subjects $)$. With respect to age, prevalence ranged from $0.46 \%(1 / 214)$ in the $18-27$ year age group to $7.52 \%(22 / 293)$ in the $48-57$ year group $(\mathrm{p}<0.001)$. Ten years later (in 1996), eight of the 1591 subjects (three females and five males, two of whom were younger than 40 years) who had been $\mathrm{HCV}-\mathrm{Ab}^{-}$in 1986 had become positive. Thus the incidence of HCV infection during the 10 year period was calculated as 50.28 cases/100 000 inhabitants per year. Furthermore, between 1986 and 1996, 2/57 subjects (one male born in 1919, one female born in 1930) spontaneously cleared HCV-Ab.

In 1999, 56 of 63 subjects who had been HCV-Ab in 1996 returned for evaluation (six subjects dropped out and one had died from HCV related liver cirrhosis). We found that in nine (originally all antibody positive and viraemic) of 56 subjects in whom the optical density (OD) of the HCV-Ab titre had decreased between 1986 and 1996, spontaneous clearance of HCV-Ab had occurred (fig 3A) Of the remaining 47 subjects who did not clear HCV-Ab, 41 showed a relatively stable high OD (range 2.0-3.5 nm), irrespective of the absence or presence 


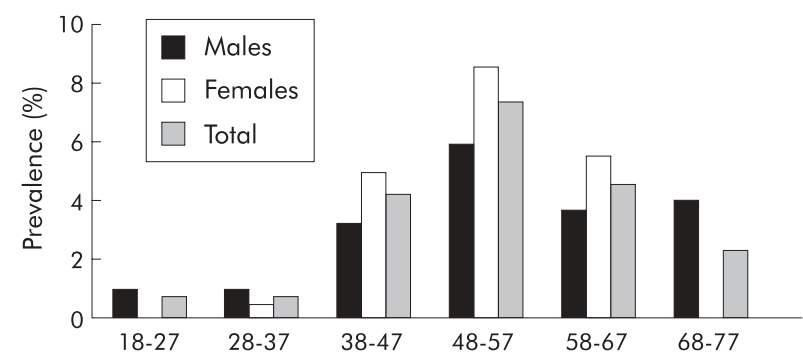

Figure 2 Prevalence of hepatitis $C$ virus antibodies in 1986 by age (in years) and sex.
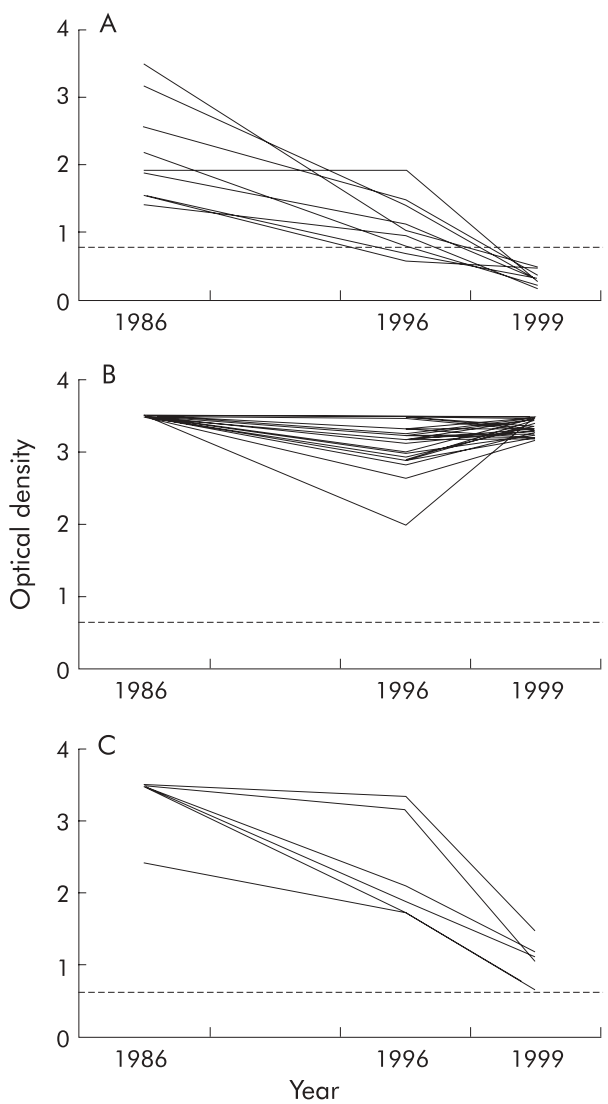

Figure 3 Optical density (OD) of hepatitis $C$ virus antibodies over time. (A) All nine subjects who had spontaneous clearance of the antibody showed reductions in OD before dropping below the cut off at $\sim 0.65 \mathrm{~nm}$. (B) Forty one of the remaining 47 subjects showed a relatively stable high OD (range 2.0-3.5 nm), irrespective of treatment (interferon $\alpha$ in seven cases). (C) Six subjects showed a progressive decrease in $\mathrm{OD}$ without actually falling below the cut off point.

of treatment (interferon $\alpha$ (IFN) in seven cases), while six showed a progressive decrease in OD without actually falling below the cut off point (fig 3B, 3C, respectively).

\section{HCV-RNA and genotype distribution}

In 1996 and 1999, 53/63 (84\%) and 37/47 (79\%) HCV-Ab ${ }^{+}$ subjects, respectively, were also positive for HCV-RNA in serum. Genotype distribution, obtained after analysing all samples positive in serum or leucocytes, is shown in fig 4 .

Among the nine subjects (all HCV-RNA ${ }^{+}$in 1986 and 1996 samples) who had lost HCV- Ab positivity between 1996 and 1999, three were still HCV-RNA positive in serum while six had lost HCV-RNA; one of these six subjects maintained HCVRNA in leucocytes (fig 5 ). Thus $1.3 \%$ per year (11/65 over 13 years) of our population with chronic infection of HCV lost

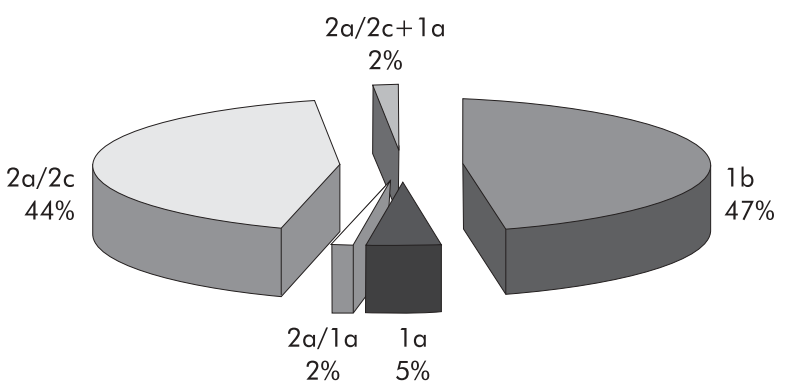

Figure 4 Distribution of genotypes in hepatitis C virus-RNA positive subjects.

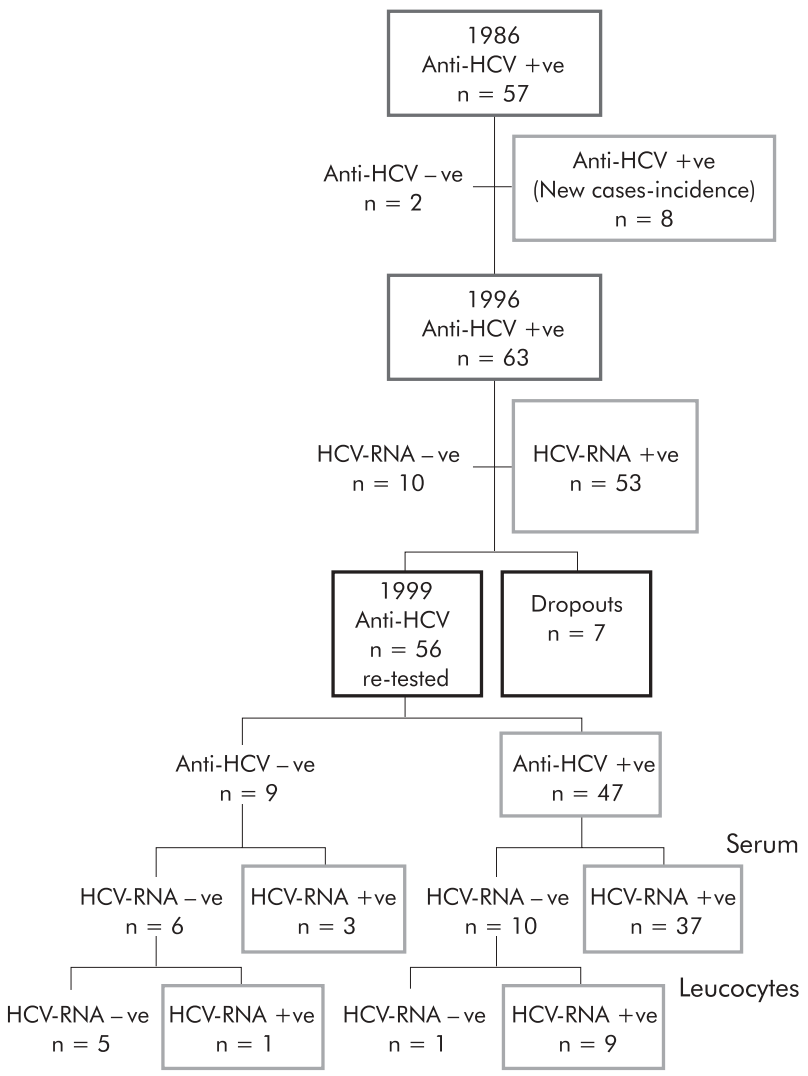

Figure 5 Algorithm representing the results obtained from testing of our population.

anti-HCV antibody and 1.1\% cleared HCV-RNA during the 13 year study period. It is noteworthy that the six subjects who showed a progressive decrease in OD without actually falling below the cut off point (see fig 3C) were all HCV-RNA ${ }^{-}$in serum; furthermore, the three subjects for whom leucocytes were available were also HCV-RNA ${ }^{-}$in leucocytes. No association was apparent between genotype and spontaneous clearance of HCV-Ab.

Remarkably, none of the seven patients treated with IFN (three of whom were type $2 \mathrm{a}$ and four type $1 \mathrm{~b}$ ) lost HCV-RNA.

\section{Liver enzymes}

In 1996, ALT levels were abnormal in 11\% (183/1646) of the tested population. Among 183 subjects with abnormal ALT levels, 27 (14.8\%) were $\mathrm{HCV}-\mathrm{Ab}^{+}$(and 26/27 were also HCV-RNA ${ }^{+}$. Anti-HCV-Ab ${ }^{+}$subjects had significantly higher ALT levels than controls (females, $\mathrm{p}<0.005$; males, $\mathrm{p}<0.001$ ).

Among 53 HCV-RNA positive subjects, 36 (67.92\%) had normal ALT levels. However, HCV-RNA positive subjects had significantly higher ALT values than those who were HCVRNA negative $(\mathrm{p}<0.05)$. Genotype 1 was associated with 
abnormal ALT levels more frequently than genotype 2 $(p<0.05)$. It is noteworthy that abnormal ALT levels were never recorded in any of the nine subjects who achieved spontaneous clearance of HCV-Ab during the course of the study. This was also the case in five of the six subjects reported in fig 3C who showed a progressive decrease in OD without actually falling below the cut off value.

\section{Intrafamilial spread}

Among the $63 \mathrm{HCV}-\mathrm{Ab}^{+}$subjects, 16 (25\%) belonged to seven families (more persons living together in the same house) containing more than one infected member. Fifty four families made up the $63 \mathrm{HCV}$ antibody positive subjects. Married couples accounted for 10 of these 16 subjects. In four of these five married couples, HCV genotype was identical in the two spouses. Two female members of these married couples had relatives infected with the same genotype with whom they had lived. It should be noted that three of the four subjects with genotype $2 \mathrm{a} / \mathrm{l} b$ were male members of the same family.

\section{Risk factors}

Risk factors for acquiring HCV infection were previous blood transfusion $(\mathrm{p}<0.001)$ and abortion $(\mathrm{p}<0.001)$ in females, performed before 1970. Data obtained in the present study underscore the importance of non-sexual forms of transmission (blades, toothbrushes, etc). However, our data based on genotype seem to confirm the importance of domestic transmission of HCV infection.

\section{DISCUSSION}

The present study expands our knowledge of the burden and natural history of HCV infection, including genotype distribution, in the general population (as opposed to groups of patients under medical surveillance). In over $60 \%$ of the period (1986-96) covered by our study, blood donors were not screened for HCV infection (in fact, two of the subjects who were found to be $\mathrm{HCV}-\mathrm{Ab}^{+}$during the study had actually been donors until 1993). Lack of screening during this period is typical of Western countries as a whole.

The present study suggests that in rural parts of northern Italy, in the context of an adult prevalence of $3.46 \%$, the adult incidence of HCV infection may have been as high as 50 cases 100000 inhabitants/year during the study period. The prevalence rate of $3.46 \%$ recorded by us in 1986 in a representative sample of two Apennine hill towns is in broad agreement with other studies of northern Italy, ${ }^{9}$ but differs considerably from data in central and southern Italy, where rates of $8 \%{ }^{6}$ and $12-26 \%,{ }^{78}$ respectively, have been reported. In line with other Italian reports, the prevalence of $\mathrm{HCV}-\mathrm{Ab}^{+}$subjects was high in the 48-57 year age range. ${ }^{8}$ This finding could either suggest that an outbreak of HCV occurred at some time in the past or that people in this age group are at greater risk of encountering sources of infection (for example, from medical or surgical procedures). Intriguingly, six of eight of the incident cases recorded by us were over 40 years of age (data not shown).

The calculated rate was 50.3 new cases/100 000 inhabitants/ year over this 10 year period. This value is somewhat higher than that of 34.2 cases/100 000 persons/year recorded in an earlier Italian study on the incidence of HCV infection. ${ }^{8}$ The high incidence rate recorded by us may be partially explained by the inadequate screening of blood donors up to 1992 (the year when the HCV-Ab screening test became compulsory for blood donors in Italy).

Most assessments of genotype distribution have been conducted in selected groups of patients under medical surveillance rather than in the general population. To our knowledge, ours is the first long term evaluation to associate assessments of HCV infection and genotype distribution in the general population. We found that genotype $\mathrm{lb}$ was the most frequent $(47 \%)$, accounting for almost half of $\mathrm{HCV}^{\mathrm{RNA}}{ }^{+}$cases, narrowly followed by genotype 2 a $(44 \%)$. This observation is in line with data from previous studies in selected groups of patients ${ }^{16}{ }^{17}$ but differs from what has been reported previously in Italian elderly or predominantly healthy populations. ${ }^{78-21}$ Use of different methods to determine HCV genotype could explain the discrepancies.

Although it is known that HCV infection can clear spontaneously, ${ }^{22}$ no systematic data exist regarding the frequency of the phenomenon. We found that 11 of 63 subjects spontaneously cleared the antibody during the first 10 years of the study in the absence of any form of treatment. It is noteworthy that abnormal ALT transaminase levels were not found in any of these subjects during the course of the study. Our findings suggest that spontaneous anti-HCV antibody clearance may be a gradual long term process that occurs in a subset of patients with normal ALT levels. Anti-HCV clearance was always accompanied by a progressive fall off in the OD level for antibody over the course of the observation period (fig $2 \mathrm{~A})$. This behaviour contrasts with that of the majority (41/47) of the remaining $\mathrm{HCV}-\mathrm{Ab}^{+}$subjects who either maintained consistently high OD levels or showed increasing levels (fig $2 \mathrm{~B})$. On the other hand, a further group of infected subjects $(n=6)$ showed a progressive fall in OD levels (fig $2 C$ ): we believe that these subjects may be destined to achieve spontaneous clearance of the antibody in the coming years.

It should be noted that seven of the 11 subjects who achieved HCV-Ab clearance also showed spontaneous RNA viral clearance whereas the remaining four subjects remained HCV-RNA positive in serum or leucocytes. We have no reasonable explanation for this behaviour. However, the presence of residual HCV-RNA in serum or leucocytes might represent a hidden reservoir of infection. This concept could help explain the finding of new cases of nosocomial blood-borne infection..$^{23}$

Regarding interfamilial spread, our data based on genotype confirm the importance of domestic transmission of HCV infection. However, the finding that many of the cases of interfamilial spread involved siblings suggests that shared use of domestic objects (razors and other blades, toothbrushes, etc) may have played a more important role than sexual transmission..$^{24}$

In summary, we found that, in the context of an adult prevalence rate of $3.3 \%$, the adult incidence of HCV infection may be as high as 50 cases/100 000 inhabitants/year in rural northern Italy. In our study of the general population, the most common genotype was 1 , followed by $2 a / 2 c$. Study of interfamilial spreading underscores the importance of nonsexual forms of transmission (blades, toothbrushes, etc). Approximately $68 \%$ of HCV-RNA positive subjects had normal ALT values. Our findings suggest that as many as $1.3 \%$ per year of infected subjects may spontaneously clear the virus from the circulation and have no clinical or biochemical signs of liver disease. In our series, none of the subjects who spontaneously cleared the virus had abnormal ALT levels. Our results also suggest that leucocytes may represent a hidden reservoir for the virus. Therefore, we believe that determination of HCVRNA in leucocytes is advisable in $\mathrm{HCV}-\mathrm{Ab}^{-}$patients who are aware of having previously been $\mathrm{HCV}-\mathrm{Ab}^{+}$.

\section{ACKNOWLEDGEMENTS}

We thank Domenico Panuccio MD for helping to coordinate the study and Loiano family doctors Licia Gaggioli MD, Claudia Gaggioli MD, De Stefano MD, Stoico MD, Navarra MD, and Zannini MD. We are also grateful to Antonio Morselli-Labate MathD for statistical analysis and to Robin MT Cooke MA for many valuable suggestions regarding the manuscript.

\section{Authors' affiliations}

C Mazzeo, F Azzaroli, Dipartimento di Medicina Interna e

Gastroenterologia, Università degli Studi di Bologna, and CRBA /Centro 
di Ricerca Biomedica Applicata), Policlinico S Orsola-Malpighi, Bologna Italy

S Giovanelli, D Festi, A Colecchia, A Miracolo, P Natale, G Nigro, E Roda, G Mazzella, Dipartimento di Medicina Interna e

Gastroenterologia, Università degli Studi di Bologna, Bologna, Italy

A Dormi, Dipartimento di Medicina Clinica e Biotecnologia Applicata

Università degli Studi di Bologna, Bologna, Italy

A Alberti, Dipartimento di Medicina Clinica e Sperimentale-Università degli Studi di Padova, Padova, Italy

\section{REFERENCES}

1 Wasley A, Alter M. Epidemiology of Hepatitis C: geographic differences and temporal trends. Sem Liv Dis 2000: 20:1-16.

2 Alter MJ, Kruszon-Moran D, Nainan OV, et al. The prevalence of hepatitis C virus infection in United States, 1988 though 1994. N Engl J Med 1999;341:556-62.

3 EASL International Consensus Conference on hepatitis C Consensus Statement. J Hepatol 1999; 31(suppl 1):3-8.

4 Bellentani S, Miglioli L, Masutti F, et al. Epidemiology of hepatitis C virus infection in Italy: the slowly unraveling mystery. Microbes Infect 2000;2: 1757-63

5 Bellentani S, Tiribelli C, Saccoccio G, et al. Prevalence of chronic liver disease in the general population of northern Italy: The Dionysios Study. Hepatology 1994;20:1442-9.

6 Stroffolini T, Menchinelli M, Taliani G, et al. High prevalence of hepatitis $C$ virus infection in a small central Italian town: lack of evidence of parenteral exposure. Ital J Gastroenterol 1995;27:235-8.

7 Guadagnino V, Stroffolini T, Rapicetta $M$, et al. Prevalence, risk factors, and genotypes distribution of hepatitis $C$ virus infection in the general population: a community- based survey in southern Italy. Hepatology 1997;26:1006-11.

8 Osella AR, Misciagna G, Leone A, et al. Epidemiology of hepatitis C virus infection in an area of Southern Italy. J Hepatology 1997; 27:30-5

9 Attili AF, Carulli N, Roda E, et al. Epidemiology of gallstone disease in Italy: prevalence data of the Multicenter Italian Study on Cholelithiasis (M.I.COL.). Am J Epidemiol 1995;141:158-65

10 Caudai C, Padula MG, Bastianoni I, et al. Antibody testing and RT-PCR results in hepatitis $C$ virus infection: HCV-RNA detection in PBMC of plasma viremia negative $\mathrm{HCV}$ - seropositive persons. Infection 1998;26:151-4.
11 El-Awady MK, Ismail SM, El Sagheer M, et al. Assay for hepatitis C virus in peripheral blood mononuclear cells enhances sensitivity of diagnosis and monitoring of HCV-associated hepatitis. Clin Chim Acta 1999;283:1-14.

12 Hofgärtner WT, Kant JA, Weck KE. Hepatits $C$ virus quantitation: optimization of strategies for detecting low-level viremia. J Clin Microbiol 2000;38:888-91.

13 Stuyver L, Rossau R, Wyseur A, et al. Typing of hepatitis $C$ virus isolates and characterization of new subtypes using a line probe assay. J Gen Virol 1993;74:1093-102.

14 Okamoto $H$, Tokita H, Sakamoto $M$, et al. Characterization of the genomic sequence of type $V$ (or $3 a$ ) hepatitis $C$ virus isolates and $P C R$ primers for specific detection. J Gen Viral 1993;74:2385-90.

15 Simmonds P, Alberti A, Alter HJ, et al. A proposed system for the nomenclature of hepatitis $C$ viral genotypes. Hepatology 1994; 19:1321-4.

16 Roffi L, Ricci A, Ogliari C, et al. HCV genotypes in northern Italy: a survey of 1368 histologically proven chronic hepatitis C patients. J Hepatol 1998;29:701-6.

17 Giannini C, Giannelli F, Monti M, et al. Prevalence of mixed infection by different hepatitis $C$ virus genotypes in patients with hepatitis $C$ virus-related chronic liver disease. J Lab Clin Med 1999:134:68-73.

18 Monica F, Lirussi F, Nassuato G, et al. Hepatitis $C$ virus infection and related chronic liver disease in a resident elderly population: the Silea study. J Viral Hepat 1998;5:345-51.

19 Maggi G, Armitano S, Brambilla L, et al. Hepatitis $C$ infection in an Italian population not selected for risk factors. Liver 1999:19:427-31.

20 Bellentani S, Pozzato G, Saccoccio G, et al. Clinical course and risk factors of hepatitis $C$ virus related liver disease in the general population: report from the Dionysos study. Gut 1999;45:874-80.

21 Prati D, Capelli C, Zanella A, et al. Influence of different hepatitis C virus genotypes on the course of asymptomatic hepatitis virus $C$ infection. Gastroenterology 1996:110:178-83.

22 Barrett S, Goh J, Coughlan B, et al. The natural corse of hepatitis C virus infection after 22 years in a unique homogenous cohort: spontaneous viral clearance and chronic HCV infection. Gut 2001;49:423-30.

23 Schvarcz R, Johansson B, Nystrom B, et al. Nosocomial transmission of hepatitis $C$ virus. Infection 1997;25:74-7.

24 Caporaso N, Ascione A, Stroffolini T. Spread of hepatitis C virus infection within families. Investigators of an Italian Multicenter. J Viral Hepat 1998;5:67-72. 